\title{
Analytical studies of BTTT used for Identification of different brands of mustard oils available in markets of India using Bellier Turbidity Temperature Test (BTTT)
}

\author{
Shashikant Pardeshi
}

DPHL, Jalgaon, Maharashtra, India

\begin{abstract}
The BTTT method is cheaper, easier, requires little laboratory infrastructure and recognized as a convenient qualitative tool for identification of different variety of oils. In this study BTTT is applied on Mustard oils and found that BTTT can be easily used as qualitative tool for identification of purity of Mustard oil from different brands available in Indian market. In this study an attempt has been made to investigate the applicability of BTTT to mustard oils obtained from different parts of India and thereby examine the influence of geographical variations on BTTT. In the present work, the mustard oils used for analysis, such as Kacchi ghani mustard oil grade-1(Kgmu,Panghat), Pure Kacchi ghani mustard oil (Pkgmu, Fortune), Kacchi ghani mustard oil (Kgmu1, Emami), refined mustard oil (Rmu, Saffola) and Mustard oil (Mu,Anupam gold) exhibited BTT in the range of 19 to $21.0{ }^{0} \mathrm{C}$. The result have demonstrated the reproducibility through the analyzed data. Hence It is observed that mustard oil fulfils BTTT values as per Regulation (Food Products and Standards) 2011 of Food Safety Standards and Act 2006. The coefficient of variation is in between 0.24-0.43 in case of BTT.
\end{abstract}

Keywords: Vegetable oil, mustard seed oil, BTTT

\section{Introduction and objective}

The quality characteristics of fats and oils is dictated by several physical such as texture, density, specific gravity, colour, refractive index etc and chemical parameters such as acid value, iodine value, saponification value, unsaponifable matter BTT etc are dependent on the source of oil; geographic, climatic, and agronomic variables of growth. Thus one must assess quantitatively the influence of these variables on characteristics of oils and fats; in present case on characteristics of mustard oil, Bellier Turbidity Temperature Test (BTTT) (acetic acid method) is used as a qualitative method for identification of pure mustard oil. Sometimes it is observed that mustard oil fulfils all specifications of refined oil but fails to pass BTTT. Moreover Mustard from different geographical locations differs in oil content. Mustard oil extracted from seasonal crops Brassica nigera, B.Junea and B. hitra has enormous edible and non-edible uses in India. The oil is consumed after extraction from mustard seeds, generally without any further processing, high price and dark colour of oil make it vulnerable for adulteration. But there are some distinct physical and chemical parameters like refractive index, specific gravity, iodine value, colour, essential content ,unsaponifable composition, acid value, Free fatty acid content, peroxide value, $\mathrm{P}$-anisidine value of the oil helps to determine its conformity as safe and standard edible oil by which the purity check of mustard oil can be done. The Bellier figure or the temperature at which turbidity appears in a specified and neutralised oil sample under specified conditions was first proposed by Bellier and modified by several workers including Franz and Adler. According to Ever in 1912, the addition of sufficient acetic acid used instated of $1 \%$ hydrochloric acid succeeding modifications in the BTT. This had been adopted by several workers and gives satisfactory results for sufficient to judge the purity of mustard oil and admixture of oils. In most cases the Bellier figure increases with the $\%$ of mustard oil in the mixture. The increase is not proportional and there is a steep rise for the $\%$ of peanut oil below $25 \%$ [1]. The objective of the present studies was to investigate analytical study of the applicability of BTTT to mustard oils of different brands available in markets obtained from different parts of India and thereby examine the influence of geographical variations on BTTT as tool for identification of mustard oil.

\subsection{Literature review}

Vegetable oils consists primary a large molecules are called triglyceride of fatty acids. Triglycerides are 
insoluble in water and greasy to touch .They are extracted from seeds of plants such as sunflower, soybean, mustard and mustard oil. Vegetable oils are used for various purposes like for cooking, for industrial use, for pet food additive etc. In India vegetable oil are widely used in frying, backing and other types of cooking. It is also used in food preparation and flavoring such as salad dressing etc. So it is also term as edible oil. Cooking oil like sunflower, soybean oil, mustard oil, mustard oil containing polyunsaturated and monounsaturated fatty acids like linoleic, Linolenic and oleic acid, although some oils that contains saturated fat, such as coconut oil, palm oil are solid. Lipid comprise a group of naturally occurring molecules that includes fats, waxes, sterols, fat soluble vitamins such as vitamin A,D,E and $\mathrm{K}$, monoglycerides, diglycerides, triglycerides, phospholipids and others. Lipid may define as hydrophobic small molecules. Lipids also encompass molecules such as fatty acids and their derivatives including mono-, di- and triglycerides [2].

Brassica juncea $\mathrm{L}$ seed has potential for use alternative source of industrial oil for shampoo, soap making and pharmaceutical creams, capsules, emulsions, fragrances, flavors, intramuscular injections, nasal sprays, ointments, plasters, and in a number of cosmetics. In addition they are also used in large quantities as raw material for bio-resources. The fatty acid profiles of Brassica juncea $\mathrm{L}$ seed oils were determined while oleic and linoleic are most prominent fatty acids in these oils, they also contain significant amounts of saturated fatty acids [3].

Rapeseed-mustard (Brassica species) is the major rabbi oilseed crop of India. Mustard seed is the second most important oil seed crop in India after soyabean accounting for nearly $20-22 \%$ of the total oilseeds produced in the country. India is the fourth producer of mustard seed contributing to around 11 $\%$ of world's total production. Rajasthan is the most giant mustard growing state and alone contributes $43 \%$ of the total mustard seed production in India [4]. The Indian agriculture is considered to be the backbone of Indian economy. The agricultural sector is the largest employer in India's economy and employed $49 \%$ of its total workforce in 2014 but contributes to a declining share of its GDP (17\% in 2013-14).A large number of important industries like jute, textiles, edible oils, tobacco, sugar, etc. Receive the raw materials produced by agriculture sectors. Edible oilseeds are an essential part of Indian agriculture and contribute more than 10percentto agriculture GDP. Soybean, mustard and rapeseedmustard are the major oilseed crops in India contributing nearly $79 \%$ and $88 \%$ to its total acreage and production, respectively. During 2012-13, rapeseed-mustard contributed $24.2 \%$ to the total oilseeds production. Globally, India account for $19.29 \%$ and $11.27 \%$ of the total area and production of mustard. Edible Oil production in India has increased at a $2.6 \%$ over past six years led by growth in Soybean Oil (3.4\%) and Rapeseed Oil (3.8\%)[4].

The solubility of oils in various solvents is a constant, depending on the nature of the glycerides composing the oil. Fryer and Weston found that a mixture of equal volume of $92 \%$ ethyl alcohol and pure amyl alcohol used as a solvent for turbidity. In Valenta test, acetic acid was used as a solvent, the results are affected by the presence of moisture in the oil and free fatty acid which lower the turbidity temperature, increasing the solubility of the oils, which raises the turbidity temperature [1].

The modified BTT test has been used by Ever for judging the purity of oils and has been found simple, rapid and fairly accurate for routine analysis as compared to the results obtained by Valenta test. Moreover, it can be conveniently used in the analysis of soap and commercial fatty acids and also for determining the $\%$ of two mixed oils. Others workers have also successfully used the same test for determining adulteration of mustard oil in some edible oils and also suggested its analytical importance. Besides the turbidity temperatures obtained with fatty acids by the method of fryer and Weston are different from those for the respective oils, depending on the difference in the solubility of the glycerides of the oil and its fatty acids in the same solvent [6].

Table-1 Shows BTT standards/values for some edible vegetable oils under 2.2: Fats, oils and Fat emulsions as per FSSA 2006[7]

\begin{tabular}{|c|c|c|c|}
\hline $\begin{array}{l}\mathrm{Sr} \\
\dot{\mathrm{N}} \\
\mathrm{O}\end{array}$ & Item No & Vegetable oil & $\begin{array}{l}\text { BTT } \\
\text { limits }\end{array}$ \\
\hline 1 & 2.2 .1 .2 & Cotton seed oil & $\begin{array}{l}19.0 \\
21.0^{0} \mathrm{C}\end{array}$ \\
\hline 2 & 2.2.1.3 & groundnuts oil & $\begin{array}{l}39.0^{-} \\
41.0^{0} \mathrm{C}\end{array}$ \\
\hline 3 & 2.2 .1 .6 & $\begin{array}{l}\text { Rape seed oil } \\
\text { Mustard oil (toria } \\
\text { oil) }\end{array}$ & $\begin{array}{l}23.0-27.5 \\
{ }^{0} \mathrm{C}\end{array}$ \\
\hline 4 & 2.2 .1 .7 & $\begin{array}{l}\text { Rape seed oil or } \\
\text { Mustard oil-Low } \\
\text { erucic acid }\end{array}$ & $\begin{array}{l}\text { Not more } \\
\text { than } \\
19.0^{0} \mathrm{C}\end{array}$ \\
\hline \multirow[t]{2}{*}{5} & \multirow[t]{2}{*}{2.2 .1 .8} & Virgin olive oil & $\begin{array}{l}17.0^{\circ} \mathrm{C} \\
\operatorname{Max}\end{array}$ \\
\hline & & Refined olive oil & $\begin{array}{l}17.0^{\circ} \mathrm{C} \\
\operatorname{Max}\end{array}$ \\
\hline 6 & 2.2 .1 .10 & $\begin{array}{l}\text { Safflower seed oil } \\
\text { (barrey ka tel) }\end{array}$ & $\begin{array}{l}\text { Not more } \\
\text { than } \\
16.0^{0} \mathrm{C}\end{array}$ \\
\hline 7 & 2.2 .1 .12 & $\begin{array}{l}\text { Til oil } \\
\text { (Gingelly/safflow } \\
\text { er oil) }\end{array}$ & $\begin{array}{l}\text { Not more } \\
\text { than } \\
22.0^{\circ} \mathrm{C}\end{array}$ \\
\hline 8 & 2.2 .1 .13 & $\begin{array}{l}\text { Niger seed oil } \\
\text { (sargiya ka tel) }\end{array}$ & $\begin{array}{l}25.0- \\
29.0^{0} \mathrm{C}\end{array}$ \\
\hline 9 & 2.2 .1 .17 & Almond oil & $\begin{array}{l}\text { Not more } \\
\text { than } \\
60.0^{0} \mathrm{C}\end{array}$ \\
\hline
\end{tabular}


The following table2 shows that the imposition of BTT values to raise the issue pertaining to the discrepancy in BTT for the presence of other vegetable oils (Admixtures of oils) in mustard oil[9]

\begin{tabular}{|c|c|c|c|c|}
\hline $\begin{array}{l}\text { Name of } \\
\text { Oil }\end{array}$ & $\begin{array}{l}\text { Prosecution } \\
\text { name }\end{array}$ & $\begin{array}{l}\text { Yea } \\
\mathrm{r}\end{array}$ & $\begin{array}{l}\text { Under } \\
\text { PFA/FSS } \\
\text { A } \\
\text { Parameter } \\
\text { to fail }\end{array}$ & BTT \\
\hline $\begin{array}{l}\text { Mustard } \\
\text { oil }\end{array}$ & $\begin{array}{l}\text { State of } \\
\text { U.P.verses } \\
\text { SatyaNaraya } \\
\text { n Umar }\end{array}$ & $\begin{array}{l}201 \\
5\end{array}$ & $\begin{array}{l}\text { BTT and } \\
\text { others }\end{array}$ & $\begin{array}{l}\text { Exceed } \\
\text { the } \\
\text { maximum } \\
\text { requireme } \\
\text { nt }\end{array}$ \\
\hline $\begin{array}{l}\text { Mustard } \\
\text { oil }\end{array}$ & $\begin{array}{l}\text { Balkrinshna } \\
\text { verses state } \\
\text { of Delhi } \\
\text { administrati } \\
\text { on }\end{array}$ & $\begin{array}{l}201 \\
4\end{array}$ & $\begin{array}{l}\text { BTT and } \\
\text { others }\end{array}$ & $\begin{array}{l}\text { Exceed } \\
\text { the } \\
\text { maximum } \\
\text { requireme } \\
\text { nt }\end{array}$ \\
\hline $\begin{array}{l}\text { Rapesee } \\
\mathrm{d} \text { oil }\end{array}$ & $\begin{array}{lr}\text { Rakeshkuma } \\
\text { r } \quad \text { Arora } \\
\text { verses } & \text { State } \\
\text { of } & \text { Delhi } \\
\text { administrati } \\
\text { on }\end{array}$ & $\begin{array}{l}201 \\
4\end{array}$ & $\begin{array}{l}\text { BTT and } \\
\text { others }\end{array}$ & $\begin{array}{l}\text { Exceed } \\
\text { the } \\
\text { maximum } \\
\text { requireme } \\
\text { nt }\end{array}$ \\
\hline $\begin{array}{l}\text { Mustard } \\
\text { oil }\end{array}$ & $\begin{array}{l}\text { Mahindar } \\
\text { Prakash , } \\
\text { New Delhi } \\
\text { administrati } \\
\text { on }\end{array}$ & $\begin{array}{l}201 \\
4\end{array}$ & $\begin{array}{l}\text { BTT and } \\
\text { others }\end{array}$ & $\begin{array}{l}\text { Exceed } \\
\text { the } \\
\text { maximum } \\
\text { requireme } \\
\text { nt }\end{array}$ \\
\hline $\begin{array}{l}\text { Mustard } \\
\text { oil }\end{array}$ & $\begin{array}{l}\text { Gori } \\
\text { Shankar } \\
\text { verses states } \\
\text { of Rajasthan }\end{array}$ & $\begin{array}{l}197 \\
4\end{array}$ & $\begin{array}{l}\text { BTT and } \\
\text { others }\end{array}$ & $\begin{array}{l}\text { Exceed } \\
\text { the } \\
\text { maximum } \\
\text { requireme } \\
\text { nt }\end{array}$ \\
\hline $\begin{array}{l}\text { Mustard } \\
\text { oil }\end{array}$ & $\begin{array}{l}\text { Jagdish } \\
\text { Prasad Alias } \\
\text { jagdish } \\
\text { verses State } \\
\text { of West } \\
\text { bengal } \\
\end{array}$ & $\begin{array}{l}197 \\
1\end{array}$ & $\begin{array}{l}\text { BTT and } \\
\text { others }\end{array}$ & $\begin{array}{l}\text { Exceed } \\
\text { the } \\
\text { maximum } \\
\text { requireme } \\
\text { nt }\end{array}$ \\
\hline $\begin{array}{l}\text { Mustard } \\
\text { oil }\end{array}$ & $\begin{array}{l}\text { Sohan singh } \\
\text { alias swaran } \\
\text { singh verses } \\
\text { State of U.P. }\end{array}$ & $\begin{array}{l}200 \\
0\end{array}$ & $\begin{array}{l}\text { BTT and } \\
\text { others }\end{array}$ & $\begin{array}{l}\text { Exceed } \\
\text { the } \\
\text { maximum } \\
\text { requireme } \\
\text { nt }\end{array}$ \\
\hline $\begin{array}{l}\text { Mustard } \\
\text { oil }\end{array}$ & $\begin{array}{l}\text { Sheo charan } \\
\text { S/o Ram } \\
\text { Chandra } \\
\text { sahai verses } \\
\text { State U.P. }\end{array}$ & $\begin{array}{l}200 \\
0\end{array}$ & $\begin{array}{l}\text { BTT and } \\
\text { others }\end{array}$ & $\begin{array}{l}\text { Exceed } \\
\text { the } \\
\text { maximum } \\
\text { requireme } \\
\text { nt }\end{array}$ \\
\hline $\begin{array}{l}\text { Mustard } \\
\text { oil }\end{array}$ & $\begin{array}{ll}\text { Laldas } & \text { sahu } \\
\text { verses } & \text { State } \\
\text { of U.P. } & \end{array}$ & $\begin{array}{l}198 \\
6\end{array}$ & $\begin{array}{l}\text { BTT and } \\
\text { others }\end{array}$ & $\begin{array}{l}\text { Exceed } \\
\text { the } \\
\text { maximum } \\
\text { requireme } \\
\text { nt }\end{array}$ \\
\hline $\begin{array}{l}\text { Mustard } \\
\text { oil }\end{array}$ & $\begin{array}{l}\text { Netai } \\
\text { Chandra and } \\
\text { others verses } \\
\text { corporation } \\
\text { of culcutta }\end{array}$ & $\begin{array}{l}196 \\
5\end{array}$ & $\begin{array}{l}\text { BTT and } \\
\text { others }\end{array}$ & $\begin{array}{l}\text { Exceed } \\
\text { the } \\
\text { maximum } \\
\text { requireme } \\
\text { nt }\end{array}$ \\
\hline
\end{tabular}

All the above Mustard oil sample did not conform to the standards laid down for the mustard oil under Prevention of food Adulteration Act 1954 and rules and Food safety standards Act2006 and rules and regulations, thereof, in that BTT values falls above the maximum requirement of $27.5^{\circ} \mathrm{C}$.

\subsection{Material and Experimental procedures \\ 1.3.1 Materials}

All the chemicals and reagents were analytical grade and used as received. Five mustard oils of different brands such as Kacchi ghani mustard oil grade1(Kgmu,Panghat), ,Pure Kacchi ghani mustard oil (Pkgmu, Fortune),Kacchi ghani mustard oil (Kgmu1, Emami), refined mustard oil (Rmu, Saffola) and Mustard oil (Mu,Anupam gold) were gathered from super market of different places of India. all these brands were in different forms of packaging while some were in poly packs, jar, tin and tetra pack. Since these five mustard oils were easily available for procurement. These different mustard oils are used in the investigations on BTTT in this research study.

\subsection{Experimental Methods}

1.3.2.1 Determination of Bellier turbidity temperature acetic acid Method

Pipette out one $\mathrm{ml}$ of the filtered sample of oil in a flat-bottom $100 \mathrm{ml}$ round flask, add $5 \mathrm{ml}$ of $1.5 \mathrm{~N}$ alcoholic potash heating over a boiling water bath using an air condenser After complete saponification cooling, neutralized by adding carefully dilute acetic acid and then add an extra amount of $0.4 \mathrm{ml}$ of accurately measured dilute acetic acid using phenolphthalein indicator. Add 50 $\mathrm{ml}$ of $70 \%$ alcohol and mixed well. Heat and allow the flask to cool in air with frequent shaking. Note the temperature by using calibrated thermometer at which the first distinct turbidity appears which is the turbidity temperature. This turbidity temperature is confirmed by a little further cooling which results in deposition of the precipitate. Dissolve the precipitate by heating the contents to $50^{\circ} \mathrm{C}$ over water bath, again cool as desiccated above and make a triplicate determination of the turbidity temperature $[\mathbf{5 , 8}]$. 
Table 2: BTTT of different mustard oils with accuracy on BTT

\begin{tabular}{|c|c|c|c|c|c|c|}
\hline $\begin{array}{c}\text { Name } \\
\text { of oil }\end{array}$ & $\begin{array}{c}\text { Brand } \\
\text { name }\end{array}$ & Code & $\begin{array}{c}\text { BTTT } \\
*\end{array}$ & SD & $\begin{array}{c}\text { CV } \\
\text { \% }\end{array}$ & $\begin{array}{c}\text { SE } \\
\text { M }\end{array}$ \\
\hline $\begin{array}{c}\text { Kacchi } \\
\text { ghani } \\
\text { mustard } \\
\text { oil } \\
\text { grade-1 }\end{array}$ & Panghat & Kgmu & 26.9 & $\begin{array}{c}0.2 \\
6\end{array}$ & 0.98 & 0.15 \\
\hline $\begin{array}{c}\text { Pure } \\
\text { Kacchi } \\
\text { ghani } \\
\text { mustard } \\
\text { oil }\end{array}$ & Fortune & Pkgmu & 27.3 & 0.2 & 0.95 & 0.15 \\
\hline $\begin{array}{c}\text { Kacchi } \\
\text { ghani } \\
\text { mustard } \\
\text { oil }\end{array}$ & Emami & Kgmu & 27.4 & 0.2 & 0.73 & 0.12 \\
\hline $\begin{array}{c}\text { Refined } \\
\text { mustard } \\
\text { oil }\end{array}$ & Safola & Rmu & 25.2 & 0.2 & 1.03 & 0.15 \\
\hline $\begin{array}{c}\text { Mustar } \\
\text { d oil }\end{array}$ & $\begin{array}{c}\text { Anupa } \\
\text { m gold }\end{array}$ & Mu & 27.1 & 0.3 & 1.11 & 0.17 \\
\hline
\end{tabular}

* Each value is averages of three measurements, SDstandard deviation, CV-coefficient of variance, SEMstandard mean error

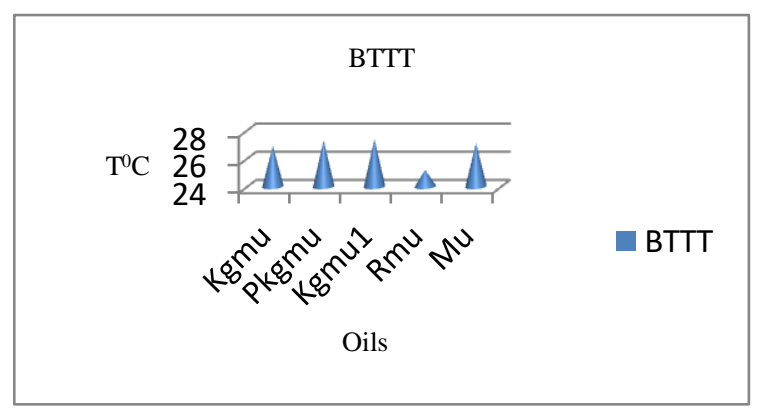

Fig.1 shows the BTTT values for different Mustard oil

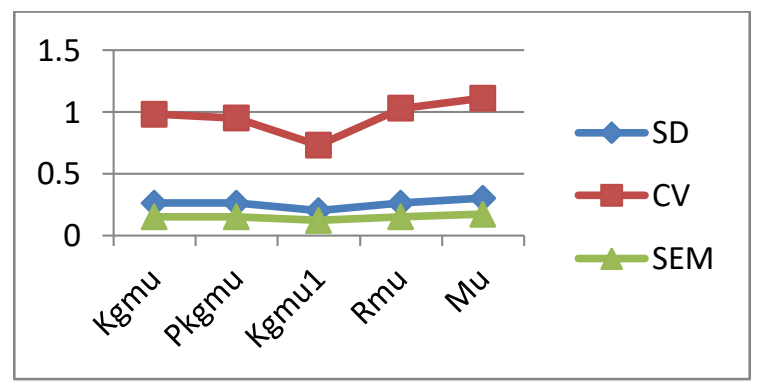

Fig.2 shows the Statistical values for different Mustard oil

\subsection{Statistical analysis:}

The data obtained from the experimental measurements and accuracy of BTTT for different brands of mustard oils have been analyzed and the Statistical parameter like standard deviation, coefficient of variance and standard mean error were calculated for both the parameters. All the experiment was carried out in triplicate and the results are presented as the mean SD, CV and SEM. Descriptive Statistics of different mustard varieties from different parts of India as shown in figure1 and 2 .

\subsection{Result and discussion}

The results obtained for BTTT from the mustard oils obtained from different places of India are shown in Table3.The prescription of the BTT test created some example of prosecution under prevention of food adulteration act 1954 and food safety act, rules and regulations 2011 and shows that the imposition of BTT values to raise the issue pertaining to the discrepancy in BTT for the presence of other vegetable oils (Admixtures of oils) in mustard oil [9]. The results obtained for BTTT for the mustard oils from five different brands of mustard oil from different places of India are shown in Table3.The data obtained from Kgmu, Pkgmu, Kgmu1, Rmu, and $\mathrm{Mu}$ displayed BTT in the range of 40 to $41^{\circ} \mathrm{C}$. As all the reported BTTT values are average of three readings, the results have demonstrated the reproducibility of the analysis data. Thus the present investigations prove with due certainty the applicability of BTTT to all seven mustard seed varieties. In particular, high oil yielding varieties were also observed to follow BTTT. Further investigations may be required to analyses the influence of seasonal variations on BTTT. Table 3 shows the accuracy, the standard deviation and coefficient is in between 0.16 and 0.43 .while in case of others it is as low as 0.1 and 0.24 .

\subsection{Recommendation}

BTT values prescribed for the certain vegetable oils comes under the mandatory food laws in some countries but due to development towards hybridization in oil seeds, reconsideration in laws is required.

\subsection{Conclusion}

The present investigations prove with due certainty about applicability of BTTT to all seven mustard seed varieties. In particular, high oil yielding varieties were also observed to follow BTTT. This study also confirms prove reliability, reproducibility and diverse applicability of BTTT. Further investigations may be required to analyses the 
influence of seasonal variations on BTTT. Wherever required, BTTT analysis can be easily supplemented with GC and HPLC analysis, which provide the quantitative data on presence of high molecular weight fatty acids in mustard oils.

\section{References}

[1] Norman Evers., The detection of archis oil in olive and almond oil, Analyst 62:96(1936).

[2] Pranjali Shinde and Shelly Gupta, Thermal degradation of fatty acids during repeatedly frying of vegetable oil: A survey review, Indian journal of research,,6(5),278-81(2017).

[3] Purendra Singh, Physico-chemical investigations of Mustard seed (Brassica juncea L) International Journal of Scientific Research in Multidisciplinary Studies,4(6), 24-27(2018).

\section{ISSN 2455-6378}

[4] Retail research mustard crop survey report (201314-15)disclaimer http://www.religareonline.com/ research/Disclaimer/Disclaimer_rcl.html

[5] Directorate General of Health Services, Manual of methods of analysis of foods (Oils and Fats) Food Safety and Standards Authority of India (FSSAI), Ministry of health and family Welfare, Government of India, New Delhi(2012).

[6] Desai C.M., Turbidity Temperature of oils as determines by Belier'sTest and Its significance as an Analytical constant, current science 16(3),9294(1947).

[7] Food safety and standards Act 2006, Rules 2008, Regulations 2011, $8^{\text {th }}$ edition Professional book publishers, New Delhi, India(2014).

[8] Indian Institution of standards, Bellier Turbidity Test, Hand book of food analysis and (part XIII)90(1984).

[9] www.indian kanoon.com regarding imposition bellier turbidity test of mustard oils through www.google.com. 